\title{
UMKM DALAM PERSPEKTIF PEMBIAYAAN INKLUSIF DI INDONESIA ${ }^{1}$ MSMES IN INCLUSIVE FINANCING PERSPECTIVE IN INDONESIA
}

\author{
Darwin \\ Pusat Penelitian Ekonomi, Lembaga Ilmu Pengetahuan Indonesia, darwin.p2e@gmail.com
}

\begin{abstract}
Abstrak
UMKM memiliki peran penting sebagai representasi ekonomi mayoritas rakyat, namun dewasa ini posisi UMKM masih lemah. Salah satu sumber masalah yang menghambat perkembangan UMKM adalah kurangnya akses pembiayaan usaha terutama dari pihak perbankan. Faktanya pihak perbankan lebih banyak memberikan kredit pada segelintir pelaku usaha yakni kelompok usaha menengah dan besar dibandingkan untuk UMKM. Kajian ini ditujukan untuk menggambarkan kondisi UMKM dan pembiayaannya serta masalah-masalah yang menyertainya. Studi ini diharapkan bisa memberikan input bagi otoritas pembangunan/pemerintah. Metode analisis kajian ini merupakan deskriptif-kualitatif yang dapat menjelaskan kondisi UMKM, pembiayaannya, dan berbagai permasalahannya. Hasil dari analisa tersebut akan menjadi dasar rekomendasi bagi perbaikan perkembangan UMKM. Meskipun merupakan mayoritas pelaku usaha di Indonesia, UMKM memiliki akses terbatas terhadap modal terutama kredit dari bank, dimana UMKM hanya memperoleh sekitar seperenam pangsa kredit nasional. Bahkan, pada tahun 2013, UMKM hanya memperoleh 3 persen pangsa kredit nasional. Upaya pengembangan skema pembiayaan UMKM yang mampu memenuhi prasyarat financial inclusion diperlukan dalam mempercepat pembangunan berkualitas. PDB yang dikuasai hanya oleh segelintir pihak merupakan ancaman bagi tujuan pembangunan dan keberadaan negara. Oleh karena itu diperlukan suatu prioritas kebijakan khususnya dalam peningkatan aksesibilitas pembiayaan untuk memperbesar kapasitas UMKM.
\end{abstract}

Kata kunci: UMKM, Kredit Mikro, Inklusif

Klasifikasi JEL: G21, G28, G30

\begin{abstract}
MSMEs have an important role as the economic representation for the majority of Indonesian of people. However, nowadays the position of UMKM is relatively weak. One source of the problems that hamper the development of MSMEs is that lack of access to business financing, especially from the banks. In fact, banks provide more credit to middle and large business groups rather than to MSMEs. This study is expected to provide inputs for development authority/ government. The method of analysis used in this study is descriptive-qualitative to explain the condition of MSMEs and their financing problems as well as the other problems. The result of the analysis will become a basis for recommendation for MSMEs development improvement. Although MSMEs is the majority of business actor in Indonesia, they have limited access to capital, especially credit from Banks, in which they only get about one-sixth of the national credit share. In fact, in 2013 MSMEs only obtain 3 percent of national credit share. The effort to develop financing scheme for MSME that met requirements of "financial inclusion" is necessary to accelerate quality development. The structure of GDP that are controlled by few parties poses a threat to the development objectives and to the State's existence. Therefore, it is necessary to have priority on policy particularly on the improvement of access to financing and the expansion of MSMEs capacity.
\end{abstract}

Keywords: MSMEs, Micro Credit, inclusive

JEL Classification: G21, G28, G30

\footnotetext{
${ }^{1}$ Makalah ini dikembangkan dari Tulisan Darwin (2017), Dinamika UMKM Dan Pembiayaan Mikro, Bab 3 Dalam Buku: Saptia, Yeni dan Nugroho, A.E. (ed), (2017), Penguatan Peran Program Kredit Mikro Dalam Mendorong Pengembangan UMKM Di Sektor Pertanian, Jakarta: LIPI-Press.
} 


\section{PENDAHULUAN}

Kemiskinan masih menjadi persoalan besar di negara-negara berkembang khususnya di Indonesia. Perdebatan tajam dan fundamental tentang kemiskinan masih berlanjut di antara tiga aliran besar paradigma kemiskinan yakni konservatif, liberal, dan radikal (Wahid, 2014). Pelopor kelompok konservatif Oscar Lewis dan Boeke menyatakan bahwa budaya masyarakat sebagai penyebab kemiskinan. Sedangkan pelopor aliran liberal Adam Smith dan Charles Valentine menyatakan bahwa kemiskinan disebabkan karena distorsi pasar terhadap akses kebutuhan masyarakat (makanan, perumahan, pakaian, dan pendidikan layak). Sementara kelompok radikal yang dimotori Karl Marx dan Dos Santos menyatakan struktur (ekonomi, sosial, dan politik) sebagai akar kemiskinan. Ketika Amartya Sen menformulasikan pergeseran pemikiran dari pembangunan ekonomi ke sosial dengan mengubah dimensi dasar dari sekadar bertumpu pada angka pertumbuhan menjadi pembangunan dalam perluasan kapabilitas manusia. Selanjutnya banyak ahli mencoba merumuskan jalan alternatif dalam pembangunan yang dapat menciptakan kemakmuran serta berdampak luas dan membawa masyarakat menuju tranformasi sosial ke arah yang lebih baik. Beberapa pemikiran tersebut muncul dari Muhammad Yunus dengan Grameen Bank-nya dan Hernando De Soto dengan legalisasi aset masyarakat agar dapat ikut meraih berbagai keuntungan dalam arus besar kapitalisme. Upaya-upaya ini diyakini akan memberikan akses dan kapasitas bankable bagi kelompok masyarakat miskin/yang selanjutnya dapat membongkar ketidakadilan dan menciptakan pertumbuhan yang dinikmati secara lebih merata oleh semua anggota masyarakat.

Terkait diskusi di atas, muncul berbagai gagasan dan tekanan kebutuhan tentang diperlukannya reformasi sistem pembiayaan/ kredit mikro yang selama ini dianggap gagal memberikan pelayanan optimal karena tidak bisa menjangkau mayoritas UMKM dan masyarakat miskin. Pembangunan yang dihasilkan dalam sistem layanan pembiayaan selama ini lebih dinikmati segelintir masyarakat dan usaha skala besar. Fokus kredit mikro tidak lagi hanya pada kredit investasi dalam layanan lembaga keuangan mikro. Saat ini telah meluas kesadaran bahwa masyarakat miskin memiliki banyak kebutuhan layanan keuangan yang berbeda (Ledgerwood, 2013). Untuk itu ekosistem pembiayaan sudah beralih pada sistem pembiayaan inklusif yang tujuan utamanya untuk memberikan berbagai layanan pembiayaan/keuangan kepada kalangan miskin dan berpenghasilan rendah.

Selama tujuh dekade lebih pembangunan ekonomi telah mengubah status Indonesia dari negara belum berkembang menjadi negara sedang berkembang. Namun apabila dibandingkan dengan beberapa negara lain, pembangunan ekonomi Indonesia relatif tertinggal dengan negara yang tadinya masih di bawah tingkat ekonomi Indonesia seperti China, Malaysia, Thailand, menyusul Vietnam dan lain-lain. Ekonomi Indonesia rata-rata tumbuh moderat (berkisar 5-6 persen pertahun) yang disertai beban berbagai masalah seperti ketimpangan pendapatan yang tinggi, lemahnya daya saing, dan lain-lain yang dapat mendorongnya masuk ke dalam middle income trap. Kenyataannya kapasitas kinerja pembangunan ekonomi Indonesia masih jauh dari kondisi memadai agar dapat mendongkrak Indonesia masuk ke kelompok negara maju. Salah satu masalah/hambatan utama adalah rendahnya keterkaitan kebijakan pembangunan dan implementasinya seperti prioritas yang seharusnya, yakni pengembangan mayoritas pelaku usaha ekonomi yakni UMKM. Sebagai contoh, lebih dari 30 tahun era rejim orde baru, orientasi kebijakan pembangunan lebih berfokus pada upaya mendorong berkembangnya konglomerasi (usaha besar). Ketika kebijakan tersebut berhasil, diharapkan akan terjadi tetesan ke bawah pada UMKM (trickle down effects). Namun ketika krisis menghantam ekonomi Indonesia tahun 1997-1998, sebagian besar usaha besar (konglomerat) tersebut mengalami kehancuran sebelum cukup meneteskan manfaat pada UMKM. Bahkan kebangkrutan itu juga membawa kerugian negara sekitar seratus empat puluh trilyun rupiah yang dikucurkan pada konglomerat tersebut melalui program BLBI (Bantuan Likuiditas Bank Indonesia) (Darwin, 2001). Seketika 
usaha besar tersebut melakukan pemutusan hubungan kerja (PHK) besar-besaran yakni sekitar 4,2 juta jiwa (Manning, 2000). Hal tersebut terjadi akibat orientasi pembangunan yang salah dengan mengganggap UMKM sulit dikembangkan dan cukup menunggu tetesan manfaat dari pengembangan usaha besar saja. Bahkan kenyataan yang terjadi sebaliknya, dimana UMKM berjasa menjadi salah satu katup penyelamat ekonomi Indonesia dengan perannya menyerap pengangguran dari PHK usaha besar tersebut. Dari 225 ribu UMKM yang di survei Kementerian Koperasi dan UKM, hanya 4 persen yang berhenti karena krisis, sedangkan 96 persen bisa bertahan, bahkan 1 persennya berkembang (Info UKM, 2004).

Sejak lama UMKM sebagai entitas mayoritas unit usaha $(99,99$ persen) yang menyerap 97 persen tenaga kerja Indonesia hampir mutlak merupakan representasi ekonomi rakyat/bangsa Indonesia. Prioritas kebijakan pembangunan yang menyentuh kepentingan pengembangan UMKM tersebut menjadi hak asasi yang harus dipenuhi. Selama ini tujuan pembangunan ekonomi inklusif yang berdaya saing selalu dideklarasikan sebagai tujuan bersama bangsa Indonesia. Namun berbagai kebijakan pembangunan yang bertumpu dan berfokus pada prioritas pengembangan UMKM relatif masih merupakan bagian kecil dari sederetan prioritas pembangunan lainnya. Agar tujuan pembangunan tersebut lebih mungkin dan lebih cepat dapat dicapai, maka berbagai kebijakan pembangunan dan implementasinya harus mempertimbangkan kebutuhan UMKM untuk bisa berkembang, bukan berangkat dari kondisi yang sulit untuk diikuti UMKM (Darwin, 2017). Sebenarnya telah banyak program pengembangan UMKM yang dikemas sebagai program pengentasan kemiskinan yang dicanangkan pemerintah, seperti Inpres IDT, INMAS, KUT, KMKP, KIK, Modal Ventura, KUK, P4K, KUBE, PEMP, UPPKS, KKPE, DAGULIR, KUR dan lain-lain. Namun faktanya mayoritas program tersebut kurang berhasil, kecuali jenis terakhir yang masih berjalan dan diharapkan akan berhasil dan berkelanjutan.

Selanjutnya studi ini direncanakan terbatas pada tinjauan teori dan fakta-fakta empiris tentang kondisi pengembangan UMKM khususnya dalam perspektif pembiayaan yang selama ini ditengarai menjadi salah satu faktor penting yang menghambat perkembangan/ kemajuan UMKM. Hasil studi ini diharapkan dapat menggambarkan kondisi UMKM dan pembiayaannya serta menghasilkan saran/ rekomendasi khususnya bagi perbaikan akses pembiayaan UMKM yang mengarah pada pembiayaan inklusif. Untuk sampai pada keberhasilan pemanfaatan kredit mikro dalam pengembangan UMKM, tentu diperlukan analisis pada zona UMKM, lembaga pembiayaan, dan lingkungan (ekosistem) keduanya. Artinya jarak yang ada antara kondisi kelayakan UMKM untuk mempunyai akses pembiayaan dengan kondisi yang layak menurut standar lembaga pembiayaan perlu diperkecil dengan menggerakkan keduanya menuju titik temunya. Pada saat yang sama kondisi lingkungan yang mempengaruhi keduanya seperti kebijakan pemerintah misalnya ikut bergerak ke arah yang dapat mendorong pertemuan keduanya.

\section{TINJAUAN PUSTAKA}

Khusus usaha mikro hampir semuanya bergerak dalam sektor informal (informality theory), tidak terdaftar, tidak memiliki ijin usaha, dan tidak membayar pajak. Usaha kecil sebagian formal dan sebagian informal, sedikit yang bayar pajak. Sedangkan usaha menengah dan sebagian usaha kecil merupakan sektor informal. Sebenarnya pemerintah berkepentingan pada pengembangan sektor informal ini (Burger et. al., 2014) karena sektor ini tidak berkontribusi terhadap pajak, produktivitas rendah, inefisien alokasi sumberdaya perekonomian, sulit berkembang karena rendahnya akses terhadap kredit, dan tidak bisa ekspor produknya. Masalahnya mayoritas UMKM adalah usaha mikro yang hampir semuanya berada dalam sektor informal dan merupakan mayoritas usaha di Indonesia, sehingga informality ini secara langsung menghambat pertumbuhan ekonomi nasional. Diskusi tentang informalitas ini banyak dilakukan para ahli (lihat: Levy, 2008; Hsieh dan Klenow, 2009; Farrell, 2004 dalam Burger et. al., 2014).

Informality ini secara langsung menciptakan hambatan-hambatan usaha 
mikro terutama dalam aktivitas-aktvitas legal-formal, mereka akan kesulitan dalam megakses program-program bantuan dari stake holder dan pembiayaan mikro perbankan dan lembaga keuangan lainnya, yang pada gilirannya membatasi pertumbuhan usaha mikro tersebut. Terdapat tiga pandangan dalam diskusi literatur informality tentang usaha mikro di negara-negara berkembang. Dua pandangan klasik yaitu model ekslusif dan model exit rasional (the rational exit model) (Perry et al., 2007 dalam Burger et. al., 2014). Pandangan ketiga menganggap informal sektor dan formal sektor adalah berbeda segmen dalam sebuah dual-economy, yang sangat tidak berhubungan (e.g. Lewis, 1954; Harris dan Todaro, 1970; Rauch, 1991 dalam Burger, 2014).

Meskipun ketiga model tersebut menyederhanakan kondisi riil, namun mereka dapat menyediakan suatu cara berpikir yang berguna tentang problem informality dan memberi kerangka tentang debat ini. Pada model ekslusif, regulasi pemerintah ditiadakan atau ditarik kembali, besar potensi mengumpulkan kewirausahaan (De Soto, 1989, 2000 dalam Wahid, 2014). Dalam pandangan model ini, usaha informal disalurkan pada energi kewirausahaan yang dapat dilepaskan dengan pengurangan regulasi entry dan mengubah lingkungan/ kondisi usaha formal (property right, pajak usaha informal). Pendekatan kedua tentang informality yaitu model exit rasional, memandang usaha UMKM secara rasional akan keluar dari sektor formal jika biaya menjadi formal lebih besar dari manfaat yang diperolehnya. UMKM akan bertahan formal jika ada manfaat formality seperti penurunan biaya registrasi formality, meningkatnya akses ke bank, hukum, kontrak dari pemerintah, atau kemudahan memperoleh tenaga kerja terampil. Pandangan ketiga, model dual ekonomi, memandang bahwa usaha informal dan usaha formal secara fundamental memang berbeda (La Porta dan Shleifer, 2014 dalam Burger, 2014). Informality merupakan produk sampingan dari kemiskinan. Usaha/ sektor informal umumya kecil, inefisien, dan dijalankan oleh pengusaha yang tidak terdidik. Produktivitas sektor informal biasanya terlalu rendah untuk bisa bertahan di sektor formal. Satu-satunya obat riil untuk informality dalam dual ekonomi hanyalah pertumbuhan ekonomi.

Dalam perspektif pembiayaan, usaha/ sektor informal mengalami rintangan. Pihak perbankan dan lembaga keuangan lainnya tidak mungkin melakukan transaksi dengan pihak usaha yang tidak ada surat menyurat resmi/formal. Kalaupun ada pinjaman perbankan dan lembaga keuangan lainnya mestilah dengan menggunakan surat-surat resmi individu (KTP, SIM, Sertifikat, dan lain-lain). Dalam pada itu, kebanyakan masyarakat miskin dan UMKM relatif enggan memanfaatkan akses pembiayaan/kredit dari pihak perbankan terutama disebabkan mereka tidak membutuhkan pembiayaan dari luar lingkungannya, selain itu rumit prosedurnya serta diharuskan adanya agunan (Ledgerwood, 2013). Hal inilah yang mendorong mereka lebih condong untuk memenuhi kebutuhan pembiayaannya dengan menggunakan akses kredit dari lembaga keuangan nonbank (LKNB) seperti koperasi, rentenir, pegadaian, keluarga, teman, dan lain-lain. Untuk mengantisipasi risiko dan biaya operasionalnya, institusi keuangan non-bank pada umumnya menetapkan tingkat bunga kredit skala kecil jauh di atas kredit perbankan (Nugroho, 2017).

Dengan akutnya masalah kemiskinan, ketimpangan, dan keterbelakangan global, Bank Dunia, IMF, dan ADB mempertegas pentingnya pencapaian inklusivitas untuk mendukung pembangunan yang inklusif. Untuk itulah salah satu prioritas penting dalam pembangunan agar terjadi akselerasi pengurangan kemiskinan di Indonesia adalah inklusivitas keuangan. Dalam hal ini, institusi keuangan diyakini berpotensi meningkatkan akumulasi kapital dalam masyarakat. PBB menyepakati tahun 2005 sebagai tahun mikrokredit (the year of microcredit), dimana akses kredit mikro berpotensi memecahkan problema kemiskinan global (Nugroho, 2017).

Keuangan inklusif telah disepakati oleh pemimpin negara-negara yang tergabung dalam G20 sebagai suatu sasaran kebijakan tahun 2010 dengan tujuan inti inklusivitas keuangan adalah untuk meningkatkan akses layanan keuangan kepada masyarakat 
miskin (Johnson \& Williams 2016 dalam Nugroho, 2017). Seperti ditegaskan oleh Bank Dunia, inklusivitas keuangan adalah upaya untuk menyediakan layanan keuangan formal kepada masyarakat miskin. Layanan keuangan ini bukan hanya skema kredit tetapi juga tabungan, alat pembayaran, dan asuransi mikro melalui institusi keuangan formal untuk mendorong pertumbuhan, efisiensi produksi, dan peningkatan kesejahteraan. Lebih luas lagi, sasaran kebijakan keuangan inklusif adalah pencapaian kondisi dimana semua kelompok masyarakat dan dunia usaha pada berbagai skala bisnis, strata sosial, dan kelas pendapatan memiliki kemampuan untuk mengakses layanan keuangan baik oleh perbankan, institusi keuangan non-bank, dan lembaga keuangan mikro (LKM) (Nugroho, 2017).

Dalam buku Keuangan Inklusif, Nusron Wahid (2014) banyak mengupas mulai dari teori-teori terkait sampai fakta-fakta empiris yang salah satunya tentang pembiayaan/ kredit mikro. Seterusnya Wahid secara intensif mengkaji tentang keuangan inklusif (financial inclusion) yang didefinisikan sebagai skema pembiayaan inklusif, dengan tujuan utama memberikan berbagai layanan keuangan kepada kalangan miskin dan berpenghasilan rendah yang meliputi kredit permodalan, tabungan, asuransi, serta layanan transfer keuangan. Layanan ini merupakan tambahan dari layanan utama pembiayaan/ kredit mikro yang sudah ada.

Kepemilikan rekening (account-holding) pada perbankan menjadi indikator utama dalam mengukur keberhasilan (outreach) dari inklusifitas keuangan. Kepemilikan rekening berarti bahwa masyarakat memiliki dan (diasumsikan) mampu menggunakan akses layanan keuangan tersebut untuk pemenuhan kebutuhan pembiayaan (financing) dan meningkatkan kegiatan ekonominya (Cheston et al 2016 dalam Nugroho, 2017)). Menurut Institusi Global Partnership for Financial Inclusion 2011 (dalam Nugroho, 2017) dan The Alliance for Financial Inclusion (AFI) (Ledgerwood, 2013) terdapat empat dimensi keuangan inklusif, yakni aksesibilitas (accesibility), pengunaan (usage), kualitas (quality) dan kesejahteraan (welfare). Aksesibilitas dimaknai sebagai kapasitas masyarakat miskin dan UMKM dalam memanfaatkan jasa keuangan. Sedangkan aspek penggunaan dipahami sebagai kemampuan masyarakat dan UMKM untuk bisa memanfaatkan jasa layanan yang ada, baik keperluan konsumtif ataupun produktif. Dimensi kualitas menggambarkan kesesuaian jasa layanan dengan kebutuhan masyarakat/UMKM, terutama kelompok miskin dan berpendapatan rendah. Sedangkan dimensi kesejahteraan mempertegas tentang keharusan keuangan inklusif mempunyai dampak bagi perbaikan kesejahteraan masyarakat miskin dan berpendapatan rendah. Pentingnya pengukuran keuangan inklusif agar dapat memahami segmen/tipe layanan keuangan yang jadi rintangan bagi masyarakat, mengapa mereka terhambat aksesnya, dan jenis layanan keuangan mana yang mereka gunakan (Ledgerwood, 2013). AFI tersebut menyatakan bahwa masingmasing dimensi di atas memerlukan koleksi data kompleks yang meningkat dan analisis serta memerlukan indikator sendiri-sendiri. Untuk aksesibilitas, indikator yang dipakai dalam mengukur menggunakan jumlah UMKM yang memanfaatkan pembiayaan perbankan. Sehubungan fokus utama bahasan dari kajian ini adalah dari sisi UMKM, maka ketiga dimensi terakhir tidak dikaji dalam bahasan.

\section{Definisi UMKM}

Di Indonesia UMKM memiliki berbagai definisi yang cenderung disesuaikan dengan kepentingan teknis yang memudahkan stakeholder mendefinisikan dalam melaksanakan tugasnya. Berbagai definisi UMKM yang dihimpun dari berbagai instansi antara lain (dalam Hubeis, hal 20, 2009).

BPS mendefinisikan UKM sebagai perusahaan atau industri yang memiliki tenaga kerja 99 orang ke bawah. Kemenkop dan UKM (UU No. 9 Tahun 1995) menyatakan UKM adalah kegiatan ekonomi rakyat berskala kecil tradisional, kekayaan bersih Rp 50 juta-200 juta (tidak termasuk tanah dan bangunan tempat usaha) dan omzet tahunan kecil sama dengan Rp. 1 milliar. Kemudian dalam UU UMKM/2008 diklasifikasikan dengan kekayaan bersih Rp. 50 juta-500 juta dan penjualan bersih tahunan Rp. 300 juta-2,5 
milliar. Sementara, Keppres No. 16/1994 mendefinisikan UKM sebagai perusahan yang memiliki kekayaan bersih maksimum Rp. 400 juta. Pendefinisian yang berbeda-beda ini dilakukan pula oleh Deperindag, Depkeu, Depkes, dan Kemenko Bidang Kesejahteraan Rakyat Republik Indonesia.

Dari sisi pendefinisian saja bisa dikatakan betapa semrawutnya persepsi tentang UMKM. Persepsi yang berbeda-beda ini baru di kalangan stakeholder dari pemerintah, belum dari berbagai pihak non-pemerintah lainnya. Masing-masing pihak/instansi pemerintah memberikan definisi yang disesuaikan pada kemudahan/kepentingan pelaksanaan tugas masing-masing agar capaian kinerja mereka bisa memenuhi target yang telah ditentukan. Jadi berbagai standar keberhasilan capaian program yang menjadi tanggung jawab masing-masing instansi bisa diperkirakan tidaklah sama, bahkan mungkin berkebalikan dengan keberhasilan pihak UMKM yang jadi obyek penyelenggaraan kewajiban berbagai intansi pemerintah tersebut.

Dalam praktek pelaksanaan tugas berbagai instansi ini banyak terjadi tumpang tindih dimana banyak UMKM yang memperoleh bantuan program dari beberapa instansi, tetapi lebih banyak lagi UMKM yang malah tidak mendapatkan bantuan program dari siapapun. Bagi UMKM yang begitu mudah dan banyak dapat bantuan yang lebih bernuansa subsidi, jelas merusak motivasinya untuk maju (moral hazard). Dengan tetap memelihara kondisinya agar selalu layak dibantu lebih menguntungkan dari pada susah-susah berjuang untuk maju. Perbedaan definisi tersebut berimplikasi pada implementasi yang berorientasi kepentingan sektoral masing-masing instansi yang tentu akan menggerogoti tingkat efisiensi dan efektivitas program-program pembangunan yang pada gilirannya membawa kerugian pada perekonomian nasional.

Dalam memberikan identifikasi tentang karakteristik UMKM terjadi pula perbedaan penekanan diantara berbagai pihak, namun secara subtansif masih relatif sama. Secara umum usaha mikro dan kecil mempunyai karakteristik sebagai berikut (Kementerian Koordinator Bidang Kesejahteraan Rakyat RI, 2009): 1. Mempunyai skala usaha yang kecil baik modal, penggunaan tenaga kerja maupun orientasi pasar; 2. Banyak berlokasi di pedesaan, kota-kota kecil atau daerah pinggiran kota besar; 3. Status usaha milik pribadi atau keluarga; 4 . Sumber tenaga kerja berasal dari lingkungan etnis/geografis yang direkrut melalui pola pemagangan atau pihak ketiga; 5. Pola kerja seringkali part-time atau sebagai usaha sampingan dari kegiatan ekonomi lainnya; 6. Memiliki kemampuan terbatas dalam adopsi teknologi, pengelolaan usaha dan administrasi sederhana; 7. Struktur permodalan sangat terbatas, kekurangan modal kerja, serta sangat tergantung sumber modal sendiri dan lingkungan pribadi; 8 . Izin usaha seringkali tidak dimiliki dan persyaratan usaha tidak dipenuhi; 9. Strategi perusahaan sangat dipengaruhi oleh kondisi lingkungan yang sering berubah secara cepat.

\section{METODE PENELITIAN}

Pada dasarnya tulisan ini dilakukan sebagai desk research yang dikembangkan dari tulisan penulis pada 2017 yang tergabung sebagai bab 3 dalam penelitian tentang "Penguatan Peran Program Kredit Mikro Dalam Mendorong Pengembangan UMKM Di Sektor Pertanian”. Penelitian ini dilakukan Tim peneliti P2E-LIPI di Jawa Timur dan Jawa Barat tahun 2015 dan selanjutnya proses untuk publikasi ilmiahnya melalui proses yang relatif panjang untuk bisa terbit yakni akhir tahun 2017. Metode pengumpulan data dan informasi tulisan ini terutama melalui pengumpulan data sekunder dan penelusuran referensi-referensi terkait. Selanjutnya metode analisisnya adalah deskriptif-kualitatif. Tujuan utama penelitian ini adalah dalam rangka memberi input dan diharapkan pada gilirannya dapat meningkatkan kesadaran otoritas pembangunan terhadap masalahmasalah yang menghambat peningkatan/ pemberdayaan mayoritas pelaku ekonomi yakni UMKM, khususnya dalam perspektif pembiayaan/keuangan yang selama ini diketahui menjadi penyebab sulitnya UMKM keluar dari kedekatannya pada zona kemiskinan. 
Tabel 1. Perkembangan Jumlah Unit Usaha Dan Tenaga Kerja, Tahun 2009-2013

\begin{tabular}{|c|c|c|c|c|c|c|c|c|}
\hline \multirow[b]{2}{*}{ Unit Usaha } & \multicolumn{3}{|c|}{ 2009* } & \multicolumn{3}{|c|}{$2013 * * *$} & \multicolumn{2}{|c|}{$\begin{array}{c}\text { Pertumbuhan } \\
\text { Rata-rata per } \\
\text { tahun }(\%)\end{array}$} \\
\hline & $\underset{\text { (buah) }}{\text { Unit Usaha }}$ & $\begin{array}{c}\text { Tenaga } \\
\text { Kerja } \\
\text { (orang) }\end{array}$ & $\begin{array}{c}\text { T. Kerja } \\
\text { per unit } \\
\text { usaha } \\
\text { (orang) }\end{array}$ & $\begin{array}{c}\text { Unit } \\
\text { Usaha } \\
\text { (buah) }\end{array}$ & $\begin{array}{c}\text { Tenaga } \\
\text { Kerja } \\
\text { (orang) }\end{array}$ & $\begin{array}{c}\text { T. Kerja } \\
\text { per unit } \\
\text { usaha } \\
\text { (orang) }\end{array}$ & $\begin{array}{c}\text { Unit } \\
\text { Usaha }\end{array}$ & $\underset{\text { Kerja }}{T .}$ \\
\hline $\begin{array}{l}\text { A. Usaha Mi- } \\
\text { kro, Kecil dan } \\
\text { Menengah }\end{array}$ & $\begin{array}{c}52.764 .603 \\
(99,99)\end{array}$ & $\begin{array}{c}96.211 .332 \\
(97,30)\end{array}$ & 1,82 & $\begin{array}{c}57.895 .721 \\
(99,99)\end{array}$ & $\begin{array}{c}114.144 .082 \\
(96,99)\end{array}$ & 1,97 & 2,35 & 4,37 \\
\hline $\begin{array}{l}\text { 1. Usaha } \\
\text { Mikro }\end{array}$ & $\begin{array}{c}52.176 .795 \\
(98,88)\end{array}$ & $\begin{array}{c}90.012 .694 \\
(91,03)\end{array}$ & 1,73 & $\begin{array}{c}57.189 .393 \\
(98,77)\end{array}$ & $\begin{array}{c}104.624 .466 \\
(88,90)\end{array}$ & 1,83 & 2,32 & 3,83 \\
\hline 2.Usaha Kecil & $\begin{array}{c}546.675 \\
(1,04)\end{array}$ & $\begin{array}{c}3.521 .073 \\
(3,56)\end{array}$ & 6,44 & $\begin{array}{c}654.222 \\
(1,13)\end{array}$ & $\begin{array}{c}5.560 .231 \\
(4,73)\end{array}$ & 8,50 & 4,59 & 12,10 \\
\hline $\begin{array}{l}\text { 3.Usaha } \\
\text { Menengah }\end{array}$ & $\begin{array}{l}41.133 \\
(0,08)\end{array}$ & $\begin{array}{c}2.677 .565 \\
(2,71)\end{array}$ & 65,00 & $\begin{array}{l}52.106 \\
(0,09)\end{array}$ & $\begin{array}{c}3.949 .385 \\
(3,36)\end{array}$ & 75,80 & 6,09 & 10,39 \\
\hline $\begin{array}{l}\text { B. Usaha } \\
\text { Besar }\end{array}$ & $\begin{array}{l}4.677 \\
(0,01)\end{array}$ & $\begin{array}{c}2.674 .671 \\
(2,70)\end{array}$ & 571,88 & $\begin{array}{l}5,066 \\
(0,01)\end{array}$ & $\begin{array}{c}3.537 .162 \\
(3,01)\end{array}$ & 698,22 & 2,02 & 7,24 \\
\hline Jumlah & $\begin{array}{c}52.769 .280 \\
(100,00) \\
\end{array}$ & $\begin{array}{c}98.886 .033 \\
(100,00)\end{array}$ & 1,87 & $\begin{array}{c}57.900 .787 \\
(100,00)\end{array}$ & $\begin{array}{c}117.681 .244 \\
(100,00)\end{array}$ & 2,03 & 2,35 & 4,45 \\
\hline
\end{tabular}

Sumber : Darwin (2017)

Keterangan : *angka sementara

*** Angka sangat-sangat sementara

\section{HASIL DAN PEMBAHASAN}

\section{Pentingnya Peran UMKM dalam Perekonomian Nasional}

\section{Kuantitas UMKM dan PenyerapanTenaga Kerja}

Perkembangan makro unit usaha menurut skala dan tenaga kerja yang diserapnya dapat menggambarkan derajat atau posisi pentingnya masing-masing kelompok unit usaha tersebut dalam aktivitas ekonomi nasional. Kontribusi jumlah UMKM menunjukkan dominasi pelaku usaha yang hampir mutlak $(99,99$ persen) yang dapat dikatakan sebagai Negara UMKM bahkan Negara Usaha Mikro (98,77 persen) (lihat tabel 1.). Dari sisi porsi unit usaha dan penyerapan tenaga kerja peranan UMKM khususnya usaha mikro sangatlah penting dibandingkan unit usaha skala lainnya yang dapat merepresentasikan ekonomi rakyat. Jika usaha mikro ini kurang memberikan nilai tambah (kenyataannya demikian), maka artinya mayoritas rakyat hidup dalam kesengsaraan, namun bila usaha mikro ini dapat ditingkatkan terus kemampuannya menghasilkan nilai tambah maka mayoritas rakyat akan hidup sejahtera.
Salah satu tujuan pokok negara ini adalah untuk mensejahterakan rakyatnya, karena mayoritas rakyat hidup dari usaha mikro ini, upaya keras untuk meningkatkan pendapatannya sudah harus selalu menjadi prioritas. Sebenarnya dominasi jumlah UMKM dan penyerapan tenaga kerjanya tidak hanya menggambarkan tingkat pentingnya UMKM, tetapi juga menggambarkan ancaman yang sangat buruk tentang terperangkapnya mayoritas rakyat dalam kehidupan yang sulit dan mendekati miskin. Selama 70 tahun merdeka kondisi ini tidak membaik secara signifikan, sudah saatnya dengan segera diperlukan upaya meningkatkan kapasitas UMKM khususnya oleh pemerintah. Secara rinci Tabel 1. menggambarkan perkembangan unit usaha menurut skalanya dan daya serap tenaga kerjanya. Nampak bahwa ada tren positif kenaikan porsi skala usaha dan penyerapan tenaga kerja kelompok usaha kecil, menengah dan besar lebih tinggi dari kenaikan usaha mikro. Jika tren ini berkelanjutan serta dapat diupayakan dalam tingkat yang lebih tinggi, maka bisa diharapkan perkembangan naik kelas dari skala usaha di bawah ke atas akan lebih banyak dan cepat terjadi, pada gilirannya di satu sisi akan menjauhkan ancaman di atas, 
bahkan di sisi lain segera mensejahterakan rakyat banyak.

Meski tumbuh positif, porsi jumlah usaha mikro agak menurun dari 98,88 persen tahun 2009 ke 98,77 persen tahun 2013. Begitu juga daya serap tenaga kerjanya menurun dari 91,03 persen ke 88,9 persen dalam periode yang sama. Jika dilihat rata-rata daya serap tenaga kerja per unit usaha, maka nampak pula bahwa usaha mikro menyerap rata-rata 1,73 orang tahun 2009 dan 1,83 orang tahun 2013. Artinya secara relatif setiap dua usaha mikro dikerjakan oleh tiga orang tenaga kerja atau rata-rata setengah dari total usaha mikro dikerjakan sendiri (tanpa buruh) dan setengahnya lagi dikerjakan oleh pemilik dengan satu tenaga kerja.

\section{Peran Terhadap PDB dan Ekspor}

Pembahasan peranan UMKM dari sisi jumlah unit usaha dan penyerapan tenaga kerja di atas memberikan gambaran betapa pentingnya eksistensi UMKM dalam perekonomian nasional bahkan bisa dikatakan hampir mutlak merepresentasikan ekonomi bangsa/rakyat. Namun ketika perhatian diarahkan pada struktur komponen penciptaan nilai tambah nasional (PDB), maka peranan UMKM apalagi usaha mikro yang mayoritas ternyata hanya memberikan peranan yang kecil. Keadaan ini tentu akan semakin memperburuk ketimpangan pendapatan, dimana mayoritas rakyat Indonesia bertumpuk hidup dari unit usaha yang memiliki pangsa rendah yang jauh dari proporsi keadilan dan cenderung mendekati miskin. Bagi stakeholder dan semua komponen bangsa seharusnya disadari bahwa hal ini merupakan ancaman terhadap tujuan pembangunan bahkan tujuan keberadaan negara. Untuk itu perlu upaya dari segenap komponen bangsa Indonesia untuk membantu penguatan UMKM khususnya dalam memberikan akses dan kapasitas untuk meraih pembiayaan/kredit mikro agar terjadi peningkatan produktivitas dan daya saing UMKM yang dapat menurunkan ketimpangan pendapatan di masyarakat serta menjauhkan ancaman di atas. Semenjak lepas dari krisis ekonomi tahun 2008, pertumbuhan ekonomi Indonesia berkisar antara 5-6 persen dengan derajat tumbuh pada usaha skala besar yang lebih tinggi. Hal ini membuat tingkat ketimpangan pendapatan meningkat, dimana pada tahun 2014 ditandai dengan indeks rasio gini Indonesia mencapai 0,41. Meskipun nilai indeks ini masih pada derajat ketimpangan sedang, namun jika pola tumbuh ekonomi tetap berlanjut lebih tinggi pada kelompok minoritas usaha besar, maka bukan tidak mungkin tingkat ketimpangan pendapatan Indonesia mencapai level ketimpangan tinggi. Di sisi lain pendapatan perkapita sedikit dibawah US $\$ 4000$ pertahun yang menempatkan Indonesia sebagai middle income country dengan pertumbuhan tahunan dibawah 8 persen diperkirakan terancam oleh perangkap stagnasi di kelas pendapatan menengah tersebut (middle income trap). Middle income trap adalah istilah bagi negara berkembang yang memiliki pendapatan menengah dan tidak dapat menaikkan pendapatannya untuk menjadi negara maju baru. Hal tersebut disebabkan mereka tidak dapat menaikan pertumbuhan ekonominya untuk cukup mampu melompat masuk ke dalam kelompok negara maju. Persoalan utama yang menahan pertumbuhan tinggi tersebut salah satunya adalah relatif rendahnya produktivitas berbagai sektor usaha. Oleh karena itu jika Indonesia menginginkan lepas dari perangkap tersebut, direkomendasikan agar tumbuh di atas 8 persen pertahun sampai masuk kelompok Negara maju (Darwin dan Lyra, 2014).

Usaha mikro yang mendominasi jumlah unit usaha dan penyerapan tenaga kerja ternyata hanya mampu berkontribusi terhadap PDB 32,66 persen tahun 2009 dan kemudian turun menjadi 30,25 persen tahun 2013 . Artinya, kontribusi yang relatif rendah dan cenderung tambah rendah seiring berjalannya waktu menunjukan bahwa pertumbuhan nilai tambah yang dihasilkan usaha mikro ini lebih rendah dari pada unit usaha skala lainnya. Keadaan ini tentu akan semakin memperburuk ketimpangan pendapatan, oleh karena itu harus segera ada upaya dari segenap komponen bangsa Indonesia untuk mendukung peningkatan produktivitas UMKM khususnya usaha mikro agar pertumbuhan nilai tambahnya minimal sama dengan usaha besar.

Di antara jenis unit usaha dalam UMKM, hanya unit usaha kecil yang tumbuh 
Tabel 2. Perkembangan PDB Menurut Unit Usaha Atas Harga Konstan 2000, Tahun 2009-2013

\begin{tabular}{|c|c|c|c|c|c|c|c|c|c|}
\hline \multirow[b]{2}{*}{ Unit Usaha } & \multicolumn{3}{|c|}{ 2009* } & \multicolumn{3}{|c|}{$2013 * * *$} & \multicolumn{3}{|c|}{$\begin{array}{c}\text { Pertumbuhan } \\
\text { Rata-rata PDB/ } \\
\text { Thn } \\
\end{array}$} \\
\hline & $\begin{array}{c}\text { PDB Har- } \\
\text { ga Konstan } \\
2000(\text { Rp } \\
\text { Miliar) }\end{array}$ & $\begin{array}{c}\text { PDB } \\
\text { Per Unit } \\
\text { Usaha } \\
\text { (Rp Juta) }\end{array}$ & $\begin{array}{c}\text { PDB } \\
\text { Per } \\
\text { Tenaga } \\
\text { Kerja } \\
\text { (Rp } \\
\text { Juta) } \\
\end{array}$ & $\begin{array}{c}\text { PDB Harga } \\
\text { Konstan } \\
\text { 2000(Rp } \\
\text { Miliar) }\end{array}$ & $\begin{array}{c}\text { PDB } \\
\text { Per Unit } \\
\text { Usaha } \\
\text { (Rp Juta) }\end{array}$ & $\begin{array}{c}\text { PDB } \\
\text { Per } \\
\text { Tenaga } \\
\text { Kerja } \\
\text { (Rp } \\
\text { Juta) }\end{array}$ & PDB & $\begin{array}{l}\text { PDB/ } \\
\text { Usaha }\end{array}$ & $\underset{\text { TK }}{\text { PDB/ }}$ \\
\hline $\begin{array}{l}\text { A. Usaha Mi- } \\
\text { kro, Kecil dan } \\
\text { Menengah }\end{array}$ & $\begin{array}{c}1.212 .599,3 \\
(58,05)\end{array}$ & 22,98 & 12,60 & $\begin{array}{c}1.536 .918,8 \\
(57,56)\end{array}$ & 26,55 & 13,46 & 6,10 & 3,68 & 1,66 \\
\hline 1.Usaha Mikro & $\begin{array}{c}682.259,8 \\
(32,66)\end{array}$ & 13,08 & 7,58 & $\begin{array}{c}807.804 .50 \\
(30,25)\end{array}$ & 14,13 & 7,72 & 4,31 & 1,95 & 0,46 \\
\hline 2.Usaha Kecil & $\begin{array}{c}224.311,0 \\
(10,74)\end{array}$ & 410,32 & 63,71 & $\begin{array}{c}342.579,19 \\
(12,83)\end{array}$ & 523,64 & 61,50 & 11,17 & 6,29 & $-8,79$ \\
\hline $\begin{array}{l}\text { 3.Usaha } \\
\text { Menengah }\end{array}$ & $\begin{array}{c}306.028,5 \\
(14,65)\end{array}$ & $7.439,98$ & 114,29 & $\begin{array}{c}386.535,07 \\
(14,48)\end{array}$ & $7.418,24$ & 97,87 & 6,01 & $-0,07$ & $-3,80$ \\
\hline B. Usaha Besar & $\begin{array}{c}876.459,2 \\
(41,95)\end{array}$ & $187.397,73$ & 327,69 & $\begin{array}{c}1.133 .396,05 \\
(42,44)\end{array}$ & $223.726,03$ & 320,43 & 6,64 & 4,53 & $-0,56$ \\
\hline Jumlah & $\begin{array}{c}2.089 .058,5 \\
(100,00)\end{array}$ & 39,59 & 21,13 & $\begin{array}{c}2.670 .314,8 \\
(100,00)\end{array}$ & 46,12 & 22,69 & 6,33 & 3,89 & 1,80 \\
\hline
\end{tabular}

Sumber : Darwin (2017)

Keterangan : *angka sementara

*** Angka sangat-sangat sementara

mengesankan jauh di atas usaha besar yakni 11,17 persen pertahun yang selanjutnya meningkatkan kontribusinya terhadap PDB dari 10,74 persen tahun 2009 menjadi 12,83 persen tahun 2013. Masalah yang agak kontradiktif pada usaha kecil ini adalah tingkat pertumbuhan nilai tambahnya yang tinggi meningkatkan kontribusinya dalam PDB dan nilai tambah perunit usahanya dari Rp. 410,32 juta ke Rp. 523,64 juta, namun nilai tambah perpekerjanya malah turun dari Rp. 63,71 juta ke Rp. 61,5 juta dalam periode yang sama. Hal ini terjadi karena pertambahan daya serap tenaga kerja usaha kecil ini juga lebih tinggi dari pertumbuhan nilai tambahnya. Secara lengkap dan rinci Tabel 2. menyajikan banyak sekali aspek dinamika perkembangan UMKM dari sisi variabel nilai tambah dengan berbagai porsi, pertumbuhan, dan perkapita unit usaha, dan tenaga kerja.

Selanjutnya, bila dilihat dari perkembangan ekspor Indonesia, maka kontribusi UMKM semakin nampak kurang signifikan. Pada tahun 2013 dari sisi unit usaha peranan UMKM adalah 99,99 persen, penyerapan tenaga kerja 89 persen, kemudian pada nilai tambah nasional 57,6 persen, selanjutnya pada sisi ekspor peranannya semakin kecil yakni hanya 15,68 persen. Keadaan ini semakin buruk karena kontribusi UMKM terhadap ekspor juga turun dari 17,02 persen tahun 2009 menjadi 15,68 persen tahun 2013. Penurunan ini merata pada tiap kelompok unit usaha di dalam UMKM. Sebaliknya minoritas unit usaha besar semakin meningkat peranannya dalam ekspor Indonesia yakni naik dari 82,98 persen tahun 2009 menjadi 84,32 persen tahun 2013. Penjelasan dari keadaan ini terutama semakin banyaknya hambatan ekspor yang datang dari semakin banyak dan kompleksnya persyaratan yang diminta, diberlakukan negara tujuan ekspor Indonesia. Persyaratanpersyaratan ekspor tersebut meliputi banyak hal mulai dari standar kualitas, standar kesehatan, standar cara berproduksi, dan lain-lainnya yang sulit dipenuhi UMKM. Oleh karena banyak negara-negara tujuan ekspor mensyaratkan proses produksi dengan ruang produksi higienis yang investasinya justru lebih banyak dari modal yang mereka milliki. Dalam hal ini tentu UMKM tidak dapat memenuhi persyaratan tersebut dan berhenti ekspor. 
Tabel 3. Perkembagan Ekspor Non-Migas Menurut Skala Unit Usaha, Tahun 2009-2013

\begin{tabular}{|c|c|c|c|c|c|c|c|c|c|}
\hline \multirow[b]{2}{*}{ Unit Usaha } & \multicolumn{3}{|c|}{$2009 *$} & \multicolumn{3}{|c|}{$2013 * * *$} & \multicolumn{3}{|c|}{$\begin{array}{c}\text { Pertumbuhan Rata- } \\
\text { rata } \\
/ \operatorname{Thn}(\%) \\
\end{array}$} \\
\hline & $\begin{array}{l}\text { Ekspor } \\
\text { (Rp mil- } \\
\text { liar) }\end{array}$ & $\begin{array}{c}\text { Ekspor/ } \\
\text { Unit } \\
\text { Usaha (Rp } \\
\text { juta) }\end{array}$ & $\begin{array}{c}\text { Ekpor/ } \\
\text { T. Kerja } \\
\text { (Rp } \\
\text { juta) }\end{array}$ & $\begin{array}{c}\text { Ekspor } \\
\text { (Rp mil- } \\
\text { liar) }\end{array}$ & $\begin{array}{c}\text { Ekspor/ } \\
\text { Unit } \\
\text { Usaha } \\
\text { (Rp.juta) }\end{array}$ & $\begin{array}{c}\text { Ekpor/ } \\
\text { T. Kerja } \\
\text { (Rp } \\
\text { juta) }\end{array}$ & $\begin{array}{l}\text { Eks- } \\
\text { por }\end{array}$ & $\begin{array}{c}\text { Eks- } \\
\text { por/ } \\
\text { Unit } \\
\text { Usaha }\end{array}$ & $\begin{array}{c}\text { Ekpor/ } \\
\text { T. } \\
\text { Kerja }\end{array}$ \\
\hline $\begin{array}{l}\text { A.Usaha } \\
\text { Mikro, Kecil } \\
\text { dan Menengah }\end{array}$ & $\begin{array}{c}162.254,5 \\
(17,02)\end{array}$ & 3,08 & 1,69 & $\begin{array}{c}182.112,7 \\
(15,68)\end{array}$ & 3,15 & 1,60 & 2,93 & 0,56 & $-1,36$ \\
\hline 1.Usaha Mikro & $\begin{array}{c}14.375,3 \\
(1,51)\end{array}$ & 0,28 & 0,16 & $\begin{array}{c}15.989,5 \\
(1,38)\end{array}$ & 0,28 & 0,15 & 2,70 & 0,0 & $-1,60$ \\
\hline 2.Usaha Kecil & $\begin{array}{c}36.839,7 \\
(3,87)\end{array}$ & 67,39 & 10,46 & $\begin{array}{c}32.051,8 \\
(2,76)\end{array}$ & 48,99 & 5,75 & $-3,42$ & $-7,66$ & $-13,89$ \\
\hline $\begin{array}{l}\text { 3.Usaha } \\
\text { Menengah }\end{array}$ & $\begin{array}{c}111.039,6 \\
(11,65)\end{array}$ & $2.699,53$ & 41,47 & $\begin{array}{c}134.071,4 \\
(11,54)\end{array}$ & $2.573,05$ & 33,95 & 4,82 & $-1,19$ & $-4,88$ \\
\hline B. Usaha & $\begin{array}{c}790.835,3 \\
(82,98)\end{array}$ & $169.090,29$ & 295,68 & $\begin{array}{c}979214,8 \\
(84,32)\end{array}$ & $193.291,51$ & 276,84 & 5,49 & 3,4 & $-1,63$ \\
\hline Jumlah & $\begin{array}{c}953.089,9 \\
(100,00)\end{array}$ & 18,06 & 9,64 & $1.161 .327,5$ & 20,06 & 9,87 & 5,06 & 2,66 & 0,59 \\
\hline
\end{tabular}

Sumber : Darwin (2017)

Keterangan : Angka dalam kurung persentase ke jumlah.

*Angka sementara *** Angka sangat-sangat sementara

Sebagian kalangan menduga bahwa hambatan yang diciptakan negara-negara tujuan ekspor Indonesia tidak semuanya murni karena alasan obyektif semata, melainkan banyak yang berupa politik dagang yang mungkin juga ada kaitannya dengan eksistensi dan dominasi usaha besar yang banyak merupakan milik asing yang terkait kepentingannya dengan negara-negara tujuan ekspor Indonesia tersebut. Dalam hal ini terasa semakin berat pekerjaan stakeholder utamanya pemerintah untuk membantu UMKM agar berkembang khususnya dalam pasar ekspor. Secara lebih lengkap dan rinci, Tabel 3. menyajikan informasi tentang berbagai aspek UMKM dalam kaitannya dengan ekspor Indonesia.

\section{Masalah UMKM}

Masalah yang dihadapi UMKM secara substansial dan intensitasnya sangat bervariasi di antara satu dengan lainnya. Masalah yang dihadapi UMKM tersebut.dapat berbeda pula di antara satu daerah dan daerah lain, antara perdesaan dan perkotaan, atau antar sektor, dan lain sebagainya yang terkait pula dengan ciri masing-masing UMKM. Jadi masalah yang dihadapi UMKM sebenarnya lebih bersifat spesifik dan individual masing-masing. Namun untuk kepentingan kebijakan dan implementasinya, memang perlu dikelompokkan berbagai permasalahan tersebut. Pengelompokan tersebut akan memandu dan memudahkan berbagai pihak berkepentingan untuk merencanakan kebijakan dan program serta implementasinya terutama terkait pengembangan UMKM. Kementerian Koordinator Bidang Kesejahteraan Rakyat mengemukan berbagai permasalahan yang masih lekat dengan keberadaan UMKM meliputi: 1. Kelemahan di bidang organisasi dan manajemen; 2. Kelemahan struktur permodalan dan keterbatasan untuk memperoleh jalur akses terhadap sumber-sumber permodalan; 3. Kelemahan memperoleh peluang (akses pasar) dan memperbesar pangsa pasar; 4. Keterbatasan pemanfaatan akses dan penguasaan teknologi terapan; 5. Rendahnya kualitas SDM yang meliputi aspek kompetensi, keterampilan, etos kerja, karakter, kesadaran akan pentingnya konsistensi mutu dan standarisasi produk dan jasa, serta wawasan kewirausahaan; 6 . Keterbatasan penyediaan bahan baku mulai dari jumlah yang dapat dibeli, standarisasi kualitas yang ada, maupun panjangnya rantai distribusi bahan baku; 7. Sistem kemitraan yang pernah digulirkan cenderung mengalami distorsi di tingkat implementasi sehingga berdampak pada subordinasinya pelaku usaha mikro, kecil, dan menengah dibandingkan dengan mitra usahanya (usaha besar); 8 . 
Efisiensi kerja rendah atau pengelolaan usaha berbiaya tinggi sehingga kurang bisa diperhitungkan secara ekonomis.

Dari perspektif pemberdayaan, berbagai kelemahan yang terkait dengan keberadaan UMKM adalah sebagai berikut: 1. Institusi yang membidangi UMKM kurang memadai; 2. Personil kurang sesuai dengan kompetensi; 3. Dukungan APBD belum memadai; 4. Beberapa Perda kurang kondusif bagi pengembangan UMKM; 5. Koordinasi lintas sektor belum optimal; 6. Lembaga pendukung pemberdayaan UMKM antara lain: lembaga keuangan, lembaga konsultasi bisnis, pusat promosi, pusat Diklat, dan pusat Litbang bagi UMKM belum optimal; 7. Kualitas SDM, dari segi keterampilan teknis maupun manajerial masih rendah; 8. Kemampuan dalam penguasaan faktor produksi, khususnya modal dan teknologi masih rendah; 9. Akses terhadap sumberdaya produktif, khususnya sumberdaya pembiayaan dari kredit perbankan masih rendah.

Hambatan yang dihadapi UMKM di NSB (Negara Sedang Berkembang) bisa berbedabeda menurut lokasi dan sektor, bahkan antar perusahaan di sektor yang sama. Namun demikian, ada sejumlah persoalan yang umum untuk semua UKM di negara mana pun juga, khususnya di dalam kelompok NSB (Tambunan, 2009). Rintangan-rintangan yang umum tersebut termasuk keterbatasan modal kerja maupun investasi, kesulitan-kesulitan dalam pemasaran, distribusi dan pengadaan bahan baku dan input lainnya, keterbatasan akses ke informasi mengenai peluang pasar dan lainnya, keterbatasan pekerja dengan keahlian tinggi (kualitas SDM rendah) dan kemampuan teknologi, biaya transportasi dan energi yang tinggi; keterbatasan komunikasi, biaya tinggi akibat prosedur administrasi dan birokrasi yang kompleks, khususnya dalam pengurusan izin usaha, dan ketidakpastian akibat peraturan-peraturan dan kebijaksanaankebijaksanaan ekonomi yang tidak jelas atau tak menentu arahnya.

Hasil penelitian dari kerjasama Kementerian Negara KUKM dengan BPS tahun 2003 (Winarni, 2006) menunjukan bahwa dari 72,47 persen UKM yang mengalami kesulitan usaha meliputi (1) Permodalan 51,09 persen, (2) Pemasaran
34,72 persen, (3) Bahan baku 8,59 persen, (4) Ketenagakerjaan 1,09 persen, (5) Distribusi transportasi 0,22 persen dan Lainnya 3,93 persen. Dari 51,47 persen responden UMKM yang mengalami kesulitan modal, hanya 17,5 persen yang meminjam modal ke bank sedangkan 82,5 persen lainnya meminjam modal ke lembaga non-bank (koperasi, perorangan, keluarga, modal ventura dan lainnya). Permasalahan UMKM yang sama menonjolnya UMKM di semua negara yakni keterbatasan modal yang terutama karena kecilnya atau tidak ada akses ke bank atau lembaga keuangan lainnya (Tambunan, 2009).

Sebenarnya seperti dikemukakan di awal tulisan, masalah internal yang menjadi domain UMKM adalah lemah/kurangnya kapasitas/kemampuan SDM dan permodalan pelaku UMKM tersebut. Jika kapasitas SDM dan permodalan pelaku UMKM bisa diperkuat dan memadai, maka masalahmasalah lanjutan seperti bahan baku, tenaga kerja, produksi, teknologi, pemasaran dan distribusi beserta akses-aksesnya akan lebih mudah mereka atasi. Masalah eksternal yang datang dari luar UMKM seperti kebijakan pemerintah, gejolak ekonomi dan politik, dan lain-lain memang seharusnya menjadi domain pemerintah untuk memperlunak atau mengatasinya. Namun dengan penguatan kapasitas SDM dan permodalan pelaku UMKM juga akan membuat mereka lebih punya daya tahan dan adaptasi serta juga mampu menyesuaikan bisnisnya dengan kondisi yang tidak terelakan.

Dengan mengutamakan kebijakan pada upaya memperkuat SDM dan permodalan pelaku UMKM, baru selanjutnya masalahmasalah lainnya, maka diyakini akan memudahkan UMKM naik kelas skala usahanya yang pada gilirannya lebih signifikan bagi pembangunan yang berkualitas yakni dengan pertumbuhan lebih merata disertai penguatan daya saing ekonomi bangsa. Untuk itu dari perspektif stakeholder terutama instansi-instansi pemerintah terkait perlu penyeragaman persepsi tentang definisi, karakteristik, dan masalah UMKM yang selanjutnya direalisasikan dalam prioritas kebijakan dan implementasi yang saling mendukung (komplementer). 
Tabel 4. Perkembangan Kredit Menurut Unit Usaha, Tahun 2011-2013

\begin{tabular}{lccccc}
\hline \multirow{2}{*}{ Unit Usaha } & \multicolumn{2}{c}{$\mathbf{2 0 1 1}$} & \multicolumn{2}{c}{$\mathbf{2 0 1 3}$} & \begin{tabular}{c} 
Pertumbuhan \\
\cline { 2 - 6 }
\end{tabular} \\
\cline { 2 - 6 } & $\begin{array}{c}\text { Nilai Kredit } \\
\text { (Rp. Miliar) }\end{array}$ & $\begin{array}{c}\text { Nilai Kredit/ } \\
\text { Usaha (Rp. } \\
\text { Juta) }\end{array}$ & $\begin{array}{c}\text { Nilai Kredit } \\
\text { (Rp. Miliar) }\end{array}$ & $\begin{array}{c}\text { Nilai Kredit// } \\
\text { Usha (Rp. } \\
\text { Juta) }\end{array}$ & $\begin{array}{c}\text { Rata-rata per } \\
\text { tahun (\%) }\end{array}$ \\
\hline A. UMKM & $\begin{array}{c}360.673^{*} \\
(16,22)\end{array}$ & 6,38 & $\begin{array}{c}506.791^{* *} \\
(15.25)\end{array}$ & 8,75 & 18,54 \\
1. Usaha Mikro & $\begin{array}{c}67.771 \\
(3,05)\end{array}$ & 1,21 & $\begin{array}{c}96.072 \\
(2,89)\end{array}$ & 1,68 & 19,06 \\
2. Usaha Kecil & $\begin{array}{c}128.877 \\
(5,80)\end{array}$ & 204,76 & $\begin{array}{c}152.892 \\
(4.60)\end{array}$ & 233,70 & 8,92 \\
3. Usaha Menengah & $\begin{array}{c}164.025 \\
(7,38)\end{array}$ & $3.347,65$ & $\begin{array}{c}257.827 \\
(7,76)\end{array}$ & $4.948,12$ & 25,37 \\
B. Usaha Besar lainnya & $\begin{array}{c}1.863 .012 \\
(83,78)\end{array}$ & $375.002,42$ & $\begin{array}{c}2.815 .892 \\
(84,75)\end{array}$ & $555.841,29$ & 22,94 \\
Jumlah & $\begin{array}{c}2.223 .685 \\
(100,00)\end{array}$ & 39,33 & $\begin{array}{c}3.322 .683 \\
(100,00)\end{array}$ & 57,39 & 22,24 \\
\hline
\end{tabular}

Sumber : Darwin (2017)

Keterangan : *4\%nya kredit kredit dengan pinjaman tertentu sebagaimana KUR

** 7,83\% kredit kredit dengan pinjaman tertentu sebagaimana KUR

\section{Kondisi Pembiayaan UMKM Dari Perbankan}

Sesungguhnya selama ini telah banyak kebijakan, program dan upaya dari berbagai pihak utamanya pemerintah. dalam pembiayaan/kredit mikro khususnya untuk UMKM. Beberapa model Pelayanan Keuangan Mikro yang sudah (pernah) ada antara lain (Kementerian Koordinator Bidang Kesejahteraan Rakyat RI, 2009):

Saving Led Microfinance, yang bertumpu pada mobilisasi dan penggalian sumber dana tabungan dari anggota kelompok atau koperasi. Contohnya adalah koperasikoperasi, LPDB dan P3KUM dari program Kemenkop-UKM, Kukesra dari program BKKBN, Dagulir dari pemda..

Credit Led Microfinance, model pelayanan keuangan yang tumbuh berdasarkan keyakinan bahwa tujuan masyarakat untuk bergabung dalam suatu kelompok dimotivasi untuk memperoleh kredit. Contoh model ini antara lain Badan Kredit Desa (BKD), Lembaga Dana Kredit Pedesaan (LDKP), Baitul Mal Wattanwil (BMT), dan Lembaga Perekonomian Desa (LPD).

Microbanking, skim perbankan yang secara khusus didesain untuk menjalankan pelayanan keuangan mikro, contoh terakhir yang paling menonjol adalah KUR, KKPE.

Linkage Model, pelayanan keuangan yang memadukan dan kelompok swadaya masyarakat KSM). Contohnya sudah dilaksanakan sebagai satu paket dalam KUR.

Dalam pada itu ada pula programprogram pengembangan keuangan mikro yang dilaksanakan berbagai instansi pemerintah pusat dan daerah. Saat ini ada program-program tersebut yang berhenti dan ada yang masih berjalan meski tidak begitu berhasil dengan baik. Meskipun sudah banyak dilaksanakan skim kredit dan programprogram yang menunjang pembiayaan untuk rakyat miskin dan UMKM, namun kenyataannya belum cukup signifikan dapat membiayai mayoritas UMKM. Penelitian BPS bekerjasama dengan Kementerian Negara KUKM tahun 2003 (Winarni, 2006), seperti telah disebutkan sebelumnya menunjukan bahwa dari 51,09 persen UMKM yang mengalami kesulitan permodalan, sebagian besarnya atau 82,5 persen mengatasi kesulitan tidak meminjam ke bank dan hanya 17,5 persen yang menyatakan yang meminjam ke bank. Sementara itu distribusi UMKM dalam kesulitan untuk mendapatkan kredit adalah; prosedur pengajuan yang sulit 30,3 persen, tidak berminat 25,34 persen, tidak punya agunan 19,28 persen, tidak tahu prosedurnya 14,33 persen, suku bunga tinggi 8,82 persen, dan proposal ditolak 1,93 persen. Dengan demikian berarti sebagian besar atau 74,66 persen responden UMKM ini merasa hambatan lebih banyak berasal dari pihak bank. Inklusivitas keuangan tidak akan memberikan banyak arti dalam memecahkan 
Tabel 5. Kredit dan Non-Performing Loan UMKM Menurut Sektor Ekonomi (Rp. Milliar)

\begin{tabular}{lcccc}
\hline \multicolumn{1}{c}{ Sektor Ekonomi } & $\mathbf{2 0 1 1}$ & $\mathbf{2 0 1 2}$ & $\mathbf{2 0 1 3}$ & $\begin{array}{c}\text { Pertumbuhan } \\
\text { Rata-rata/Thn. }\end{array}$ \\
\hline Pertanian, Perburuan dan Kehutanan & 27.192 & 40.709 & 48.193 & \\
Baki Debet & $(5,93)$ & $(7,73)$ & $(7,92)$ & 33,13 \\
NPL (\%) & 3,28 & 3,67 & 3,35 & \\
Perikanan & $2.602(0,57)$ & 2.900 & 3.707 & 19,35 \\
Baki Debet & 6,19 & $(0,55)$ & $(0,61)$ & \\
NPL (\%) & 5,62 & 4,61 & \\
Industri Pengolahan & 52.231 & 60.087 & 65.338 & 11,85 \\
Baki Debet & $(11,4)$ & $(11,41)$ & $(10,73)$ & \\
NPL (\%) & 3,83 & 3,02 & 2,89 & \\
Perdagangan Besar dan Eceran & 202.447 & 248.870 & 323.256 & 26,36 \\
Baki Debet & $(44,19)$ & $(47,28)$ & $(53,1)$ & \\
NPL (\%) & 3,69 & 3,40 & 3,29 & \\
Sektor Lainnya & & & & \\
Baki Debet & 173.692 & 173.831 & 168.329 & $-1,56$ \\
NPL (\%) & $(37,91)$ & $(33,02)$ & $27,65)$ & \\
Total semua sektor & 2,97 & 2,93 & 3,14 & \\
Baki Debet & & & & \\
NPL (\%) & 458.164 & 526.397 & 608.823 & 15,27 \\
\hline
\end{tabular}

Sumber : Darwin (2017)

problema kemiskinan dan ketimpangan, bila aksesibilitas keuangan ini tidak mampu memperkuat sinergi antara perbankan dan LKM dalam spektrum ekosistem keuangan. Sinergi ini penting untuk memperkuat pasar keuangan mikro yang kondusif bagi peningkatan kewirausahaan masyarakat miskin sehingga dapat mengaktualisasikan endowmen menjadi investasi produktif (Nugroho, 2017)

Data makro perkembangan kredit mikro menunjukan bahwa meski tumbuh positif namun ternyata pangsa kredit yang diterima UMKM hanya meliputi sebagian kecil saja yakni 16,22 persen tahun 2011 kemudian menurun menjadi 15,25 persen tahun 2013. Usaha mikro dan kecil dalam kelompok UMKM ini mengalami penurunan pangsa kredit dalam periode 2011-2013. Sedangkan usaha menengah memperoleh pangsa yang sedikit meningkat. Sementara itu pangsa kredit usaha besar juga sedikit meningkat dari 83,78 persen tahun 2011 menjadi 84,75 persen tahun 2013. Hal ini terjadi karena pertumbuhan kredit yang diperoleh usaha menengah dan besar lebih tinggi dari usaha mikro dan kecil. Kembali kontradiksi terjadi disini dimana usaha besar sebagai minoritas dari pelaku usaha $(0,001$ persen) memperoleh mayoritas pangsa kredit dengan tren yang meningkat pula. Sedangkan UMKM sebagai mayoritas pelaku usaha hanya mendapatkan pangsa yang kecil dengan tren yang menurun pula. Hal ini tentu sungguh memprihatinkan, dimana mayoritas pelaku usaha masih sulit memperoleh akses kredit dibanding usaha besar yang umumnya telah dikuasai pula oleh pihak asing. Tabel 4 menyajikan secara lengkap dan detail tentang perkembangan kredit di Indonesia.

Gambaran dominasi UKM dalam jumlah pelaku usaha dan penyerapan tenaga kerja namun merupakan kontributor kecil dalam PDB dan ekspor, serta penerima minimal kredit menunjukkan betapa rentannya ekonomi Indonesia yang bergantung pada segelintir usaha besar yang cenderung didominasi oleh pihak asing pula. Jika sewaktu-waktu terjadi gejolak ekonomi, sosial dan politik pihak usaha besar ini dengan serta merta dan mudah hengkang ke luar negeri (bahkan termasuk usaha besar domestik seperti yang terjadi pada krisis tahun 1998), sementara bangsa Indonesia kembali terpuruk dan mulai dari 
Tabel 6. Kredit dan Non-Performing Loan UMKM Menurut Jenis Penggunaan (Rp. Milliar)

\begin{tabular}{lcccc}
\hline & $\mathbf{2 0 1 1}$ & $\mathbf{2 0 1 2}$ & $\mathbf{2 0 1 3}$ & Rata-rata Pertumbuhan \\
\hline Modal Kerja & & & & \\
Baki Debet & 355.888 & 403.047 & 444.030 & 11,70 \\
NPL (\%) & $(77,68)$ & $(76,57)$ & $(72,93)$ & \\
Investasi & 3,59 & 3,39 & 3,30 & \\
Baki Debet & 102.275 & 123.250 & 164.792 & 26,94 \\
& $(22,32)$ & $(23,43)$ & $(27,07)$ & \\
NPL (\%) & 2,84 & 2,73 & 2,95 & \\
Jumlah & & & & \\
Baki Debet & 458.164 & 526.397 & 608.823 & 15,27 \\
NPL (\%) & $(100,00)$ & $(100,00)$ & $(100,00)$ & \\
\hline
\end{tabular}

Sumber : Darwin (2017)

bawah lagi. Untuk itu sangatlah penting secara bertahap namun tidak terlalu lama dominasi penguasaan usaha besar perlu dikurangi tidak dengan mengkontraksi mereka tetapi dengan mempercepat peningkatan peran UMKM dalam perekonomian Nasional melalui inklusivitas pembiayaan.

Selanjutnya data dari Bank Indonesia mengungkapkan bahwa perkembangan yang baik dari kredit yang diterima UMKM khususnya di sektor pertanian, industri pengolahan, dan perdagangan besar dan eceran. Selain itu performa pengembalian kredit ketiga sektor ini juga cukup baik dengan NPL berada pada tingkat aman yakni di bawah 5 persen (kecuali pada sub-sektor perikanan di tahun 2011 dan 2012 sedikit di atas 5 persen) di semua periode 2011-2013. Dalam pada itu kredit yang diperoleh sektorsektor lainnya di luar ketiga sektor di atas mengalami penurunan meski NPL-nya relatif bagus semua (lihat Tabel 5.).

Dilihat dari jenis pemanfaatan kredit UMKM, nampaknya didominasi untuk modal kerja, yakni 77,68 persen tahun 2011 kemudian turun menjadi 72,93 persen. Sebenarnya nilai kredit modal kerja ini tumbuh cukup tinggi yakni sekitar 11,7 persen pertahun, namun karena tingkat pertumbuhan kredit investasi jauh lebih tinggi atau sekitar 26,94 persen pertahun, maka pangsa kredit modal kerja turun sedangkan pangsa kredit investasi naik. Secara keseluruhan kredit UMKM ini tumbuh relatif baik yakni rata-rata 15,27 persen pertahun. Dari sisi performa pengembalian kredit bisa dibilang semuanya relatif baik dengan NPL di bawah rata-rata 5 persen (lihat tabel 6).
Kegagalan berbagai program kredit mikro sebelum era program KUR (Bimas, KUT, dan lain-lain) terutama karena sumber pendanaan seluruhnya dari pemerintah, tingginya kredit macet, dan ketidaktepatan sasaran penerima kredit. Walaupun penyaluran kredit dilakukan pihak perbankan, namun tetap saja tingkat kemacetan kredit mikro sangatlah tinggi, karena ketidak hati-hatian pihak bank sebagai agen penyalur (channeling agents) yang terjadi akibat risiko kredit macet menjadi tanggung jawab pemerintah sebagai sumber/sponsor pendanaan program kredit mikro tersebut. Sedangkan ketidaktepatan sasaran penerima kredit mikro juga tidak menjadi tanggung jawab pihak bank sebagai channeling. Selain itu SDM perbankan memang tidak memiliki kapasitas menentukan ketepat sasaran tersebut, melainkan lebih pada keahlian menilai risiko kredit. Selain itu, tingkat bunga kredit mikro yang jauh di bawah tingkat bunga pasar menyebabkan munculnya moral hazard baik dari penerima kredit maupun dari sebagian SDM perbankan yang menimbulkan kolusi dan berujung pada ketidaktepatan sasaran dan kemacetan kredit.

Jenis program kredit mikro yang terakhir dewasa ini dalam upaya inklusivitas pembiayaan rakyat/UMKM adalah Kredit Usaha Rakyat (KUR) yang telah dilaksanakan sejak tahun 2007 di era rejim pemerintahan SBY-JK. Penyaluran kredit program KUR sudah berdasarkan prinsip-prinsip kredit komersial yang lebih pro-pasar yang terbukti secara keseluruhan cukup sukses dengan tingkat kemacetan reklatif rendah.

Selama periode 2007-2014, program KUR telah memberikan kredit pada sekitar 
Tabel 7. Kinerja Program KUR 2007-2014

\begin{tabular}{|c|c|}
\hline Indikator & Kinerja per Desember 2014 \\
\hline Jumlah debitur KUR (akumulasi) & 12.475.927 debitur ( 11,4 juta debitur KUR Mikro $)$ \\
\hline Total Plafon KUR (akumulasi) & Rp 178,85 triliun \\
\hline Baki Debet KUR & Rp 49,54 triliun \\
\hline Penyaluran KUR Mikro & Rp 96,26 triliun (53.8\% dari total penyaluran) \\
\hline Penyaluran KUR Ritel & Rp 82,58 triliun ( $46.17 \%$ dari total penyaluran) \\
\hline NPL rata-rata & $3.3 \%($ NPL KUR Mikro = $1,6 \%)$ \\
\hline $\begin{array}{l}\text { Migrasi KUR ke Kredit Komersial (data } \\
\text { BRI posisi Oktober 2014) }\end{array}$ & 3.011.727 debitur, Plafon $=\operatorname{Rp} 31,27$ triliun \\
\hline Serapan Tenaga Kerja UMKM & 20.344 .639 \\
\hline NPG Askrindo & $3.8 \%$ \\
\hline NPG Jamkrindo & $4.15 \%$ \\
\hline PMN Askrindo & Rp 5,211 triliun \\
\hline PMN Jamkrindo & Rp 6,539 triliun \\
\hline Total pembayaran IJP (akumulasi) & Rp 5,02 triliun \\
\hline Pembayaran Klaim (akumulasi) & $\begin{array}{l}\text { Askrindo }=\mathrm{Rp} 2,25 \text { triliun } \\
\text { Jamkrindo }=\mathrm{Rp} 2,78 \text { triliun }\end{array}$ \\
\hline
\end{tabular}

Sumber: Kemenko Perekonomian (2014), dalam Nugroho (2017)

12,5 juta debitur dan sebagian besar Usaha Mikro-Kecil (UMK) yakni 11,4 juta UMK atau 91,2 persen dari total debitur KUR atau sekitar 19,6 persen dari total UMKM di Indonesia. Artinya KUR tahun 2014 telah bisa menyediakan akses bagi 19,6 persen dari total UMKM. Akumulasi penyaluran KUR dari tahun 2007 sampai tahun 2014 mencapai Rp 178,8 triliun dengan NPL rata-rata di bawah 5\%, meski beberapa bank penyalur memiliki NPL di atas 5 persen, antara lain BTN sekitar 9,5\%; BSM sekitar 8,4\%; dan $\mathrm{BPD}$ rata-rata sekitar $8,9 \%$. oleh karena bankbank yang NPL KUR-nya mendekati tingkat 10 persen tersebut, maka sejak tahun 2015 untuk sementara penyaluran KUR melalui BPD-BPD dihentikan. Dengan jumlah penempatan modal Negara (PMN) kepada PT Jamkrindo dan Askrindo sebesar Rp 11,7 triliun ditambah imbal jasa penjaminan (IJP) sebesar Rp 5 triliun, total investasi pemerintah untuk mendukung program KUR mencapai Rp 16,7 triliun. Dengan akumulasi penyaluran KUR sebesar 178,8 triliun, setiap satu rupiah yang dikeluarkan pemerintah untuk mendukung program KUR mampu mendorong mobilitas kredit sekitar Rp 10 kepada UMKM. Artinya, Program KUR memiliki daya ungkit yang signifikan terhadap penyaluran kredit perbankan kepada UMKM (Nugroho, 2017).

Meskipun secara menyeluruh kinerja program KUR relatif berjalan baik, namun, distribusi KUR masih relatif timpang secara geografis maupun sektoral. Distribusi KUR terpusat di Jawa yakni sekitar 54\% dan sektor perdangangan mencapai $57,6 \%$ dari total KUR. Selain itu Program KUR disinyalir menghadapi masalah ketidaktepatan sasaran pada masyarakat miskin karena desain program memang tidak secara spesifik ditujukan untuk RTM dengan tingkat risiko tinggi yang menyebabkan keengganan bank pelaksana menyalurkan KUR kepada RTM.

Secara keseluruhan masalah klasik bagi UMKM khususnya usaha mikro dan informal adalah rendahnya akses terhadap lembaga pembiayaan yang sekaligus memerangkapnya untuk masuk dalam jeratan rentenir. Pada tahun 2014, data Bank Indonesia menunjukkan bahwa dari 56,4 juta UMKM, baru 30 persen di antaranya yang bisa mendapat akses pembiayaan (Kompas, 2018). Sumber/akses pembiayaan ini berasal dari bank sekitar 76 persen dan dari lembaga keuangan non- bank 24 persen. Berarti secara total tahun 2014 ini perbankan hanya mampu menyediakan akses bagi sekitar 22,8 persen UMKM yang sebagian besarnya dipenuhi oleh KUR yakni bagi 19,6 persen UMKM dan jenis kredit lain memberikan akses bagi 3,2 persen UMKM. Upaya untuk meningkatkan aksesibilitas UMKM terhadap perbankan juga sudah dilakukan oleh Bank Indonesia melalui regulasi yang mendorong alokasi kredit kepada UMKM. Regulasi tersebut mengatur alokasi kredit untuk UMKM sebesar 5 persen dari total kredit tahun 2015, 10 persen tahun 
2016, 15 persen tahun 2017, dan 20 persen akhir tahun 2018 (Kompas, 2018). Selain itu akhir-akhir ini juga ada upaya memperluas akses pembiayaan UMKM dari perbankan yakni dengan diluncurkannya bank wakaf mikro.

Dengan kondisi tersedianya akses bagi sekitar 30 persen UMKM terhadap perbankan dan lembaga non-bank, berarti ada sekitar 70 persen UMKM yang tidak memiliki akses pembiayaan bank dan non-bank yang selama ini di pandang sebagai peluang oleh berbagai sumber pembiayaan lainnya terutama rentenir. Dalam kurun dua tahun terakhir ini peluang terhadap pembiayaan 70 persen UMKM sudah pula secara pesat dimasuki oleh berbagai usaha pembiayaan digital. Namun sampai saat ini mayoritas pembiayaan digital yang biasa disebut Fintech (Financial Technology) masih bersifat pembiayaan jangka pendek (1-3 bulan) dengan tingkat bunga yang tinggi dan cenderung digunakan untuk memenuhi kebutuhan mendesak.

\section{KESIMPULAN}

Setelah tujuh dekade Indonesia merdeka, pembangunan ekonomi untuk mensejahterakan yang merupakan hak asasi rakyat masih jauh dari jangkauan. Hal ini terlihat dari relatif rendahnya pendapatan riil mayoritas tenaga kerja (rakyat) (97 persen) yang bertumpuk di dalam UMKM khususnya unit usaha mikro (89 persen sampai tahun 2013) dengan harga konstan tahun 2000 hanya memiliki pangsa/ porsi nilai tambah sekitar 30,25 persen atau Rp 14,13 juta per usaha mikro atau Rp7,72 juta pertenaga kerja. Sementara Usaha besar yang hanya 0,01 persen memperoleh porsi nilai tambah sekitar 42,44 persen atau $\mathrm{Rp}$ 223,72 milliar per unit usaha atau Rp 320 juta perpekerja.

Kenyataannya, sebahagian besar nilai tambah usaha besar bukan milik pekerjanya tetapi milik segelintir pengusahanya. Ketimpangan luar biasa ini terjadi pula dalam pangsa ekspor dan pangsa kredit. Apalagi sebagian pemilik usaha besar ini adalah investor asing, berarti nilai tambah yang dimiliki mayoritas rakyat Indonesia sangatlah kecil. Secara kasar pendapatan perkapita Indonesia yang sekitar hampir US \$ 4000 atau sekitar Rp 42 juta pertahun tersebut (dari perkapita tenaga kerja usaha mikro hanya seperenamnya) adalah pemerataan dari pendapatan sedikit orang kaya dengan sangat banyak orang miskin.

Sebagai mayoritas usaha, UMKM juga memiliki "aksesibilitas" yang terbatas terhadap modal terutama kredit dari lembaga keuangan bank. UMKM yang mayoritas unit usaha di Indonesia hanya memperoleh sekitar seperenam pangsa kredit nasional meski ditengarai bahwa dengan keberadaan KUR pangsa ini meningkat jadi seperlimanya tahun-tahun terakhir ini. Bahkan kalau dilihat usaha mikro yang merupakan mayoritas unit usaha tahun 2013 yakni 98,77 persen hanya memperoleh pangsa kredit sekitar 3 persen saja. Upaya pengembangan skim kredit/ pembiayaan UMKM yang disebut sebagai bagian dari financial inclusion memang sangat diperlukan untuk melahirkan terobosan dalam mempercepat pembagunan berkualitas yakni pembangunan inklusif yang berdaya saing tinggi.

Fakta di atas rasanya cukup menjelaskan betapa ekonomi rakyat Indonesia sangat rawan dan tergantung pada segelintir pemilik usaha besar. Dengan kata lain struktur PDB yang dikuasai sedikit orang merupakan ancaman bagi tujuan pembangunan dan tujuan keberadaan negara. Oleh karena itu sangatlah perlu dan segera adanya prioritas kebijakan dan implementasinya untuk memperbesar kemampuan UMKM berkontribusi pada PDB nasional. Meski sulit untuk menemukan jalan pintas pembangunan, namun sebagai hak asasi rakyat tetap jadi keharusan stakeholder untuk mengupayakannya.

Berdasarkan analisis teori, dan studi empiris beserta permasalahan UMKM dalam perspektif pembiayaan inklusif yang berdaya saing, maka dapat disimpulkan perlunya pembinaan UMKM untuk bertambah kapasitasnya menuju sektor formal dan secara simultan perlu pula sistem pembiayaan mikro bergerak ke arah tempat pertemuan/ interseksi antara kapasitas pemenuhan syarat formalitas UMKM dan syarat-syarat minimal sistem pembiayaan mikro bisa dipenuhi agar aksesibilitas UMKM terhadap perbakan bisa dioptimalkan. Pada saat yang sama dimensi pembiayaan inklusif lainnya (penggunaan, kualitas, dan kesejahteraan) tetap perlu pula 
ditingkatkan. Sebagai fasilitator dan pembina, tentu saja peran optimal pemerintah (pusat dan daerah) diperlukan untuk mendorong bertemunya sistem pembiayaan mikro yang inklusif namun masih memiliki daya saing dengan UMKM yang ditingkatkan kapasitasnya untuk nyaman dalam sektor informal.

\section{DAFTAR PUSTAKA}

Burger, Nicholas, Dkk. (2014). Reforming Policies for Small and Medium Sized Enterprises in Indonesia. RAND Labor and Population, Project Report for TNP2K, Jakarta.

Darwin dan Lyra. (2014). Pentingnya "Scalling Up" dan Perluasan Program IPTEKDALIPI dalam Akselerasi Pertumbuhan Ekonomi Indonesia. Bulletin IPTEKDALIPI, Edisi Khusus, Jakarta, LIPI-Press.

Darwin. (2001). Ekonomi Indonesia di Antara Perekonomian Negara-Negara APEC Menjelang Globalisasi, dalam Thoha, Mahmud, Globalisasi, Krisis Ekonomi Dan Kebangkitan Ekonomi Kerakyatan. Jakarta: P2E LIPI.

Darwin. (2017). Dinamika UMKM dan Pembiayaan Mikro, dalam Saptia, Yeni dan Nugroho A.E., 2017, Penguatan Program Kredit Mikro Dalam Mendorong Pengembangan UMKM Di Sektor Pertanian, Jakarta, LIPI-Press.

Hubeis, Musa. (2009). Prospek Usaha Kecil Dalam Wadah Inkubator Bisnis. Ghalia: Indonesia, Bogor.

Info UKM. 29 Nopember 2004. Kementerian Koperasi dan UKM. Jakarta.
Kementerian Koordinator Bidang Kesra RI. (2009). Program Pengembangan Keuangan Mikro Di Indonesia. Informasi Umum: Jakarta.

Kompas,11 Mei 2018. Pembiayaan: Permudah Akses Mikro.

Ledgerwood, Joanna. (2013). The New Microfinance Handbook: A Financial Market System Perspective. Word Bank: Washington D.C

Manning,C. (2000). Labour Market Adjustment to Indonesias Economic Crisis Contex, Trend and Implications', Bulletin of Indonesian Economic Studies, Vol. 36, no. 1, pp. 105-36.

Nugroho, A.E. (2017). Politik Ekonomi Kredit Program Untuk Pemberdayaan Usaha Mikro-Kecil: Dari Bimas Hingga Kredit Usaha Rakyat, Bab 5 Dalam Buku, Saptia, Yeni dan Nugroho, A.E., (eds), 2017, Penguatan Peran Program Kredit Mikro Dalam Mendorong Pengembangan UMKM Di Sektor Pertanian, Jakarta: LIPI-Press.

Tambunan, Tulus T.H. (2009). UMKM Di Indonesia. Ghalia Indonesia: Bogor.

Tambunan, Tulus T.H. (2016). Pembangunan Ekonomi Inklusif, Sudah Sejauh Mana Indonesia?. LP3ES: Jakarta.

Wahid, Nusron. (2014). Keuangan Inklusif, Membongkar Hegemoni Keuangan; Peran Kredit Usaha Rakyat Dalam Menurunkan Kemiskinan dan Pengangguran. KPG Bekerjasama dengan Inter Café IPB dan OJK, Jakarta.

Winarni, Sri. (2006). Strategi Pengembangan Usaha Kecil Melalui Peningkatan Aksesibilitas Kredit Perbankan. Infokop Nomor 29, Tahun XXII, 2006. 
76 | Jurnal Ekonomi dan Pembangunan Vol 26, No.1, 2018 